\title{
Endechas por la pérdida de al-Andalus en dos zéjeles de Cútar
}

\author{
Lament for the loss of al-Andalus \\ in two Zajal from Cútar
}

\author{
Carmen Barceló \\ Universidad de Valencia, España
}

Se editan, traducen y comentan dos poemas estróficos en árabe dialectal andalusí, escritos en un volumen misceláneo encontrado en Cútar (Málaga). Su contenido alude a los reveses de los últimos tiempos de dominio musulmán en la Península Ibérica. Se comentan aspectos sobre el posible autor de los versos, la biografía del copista y su contexto religioso.

Palabras clave: literatura árabe; poesía estrófica; dialectal; elegía; sufismo; al-Andalus; siglo XV.
This article edits, translates, comments and examines several aspects related with two strophic poems in Andalusian Arabic dialect. They are written in a miscellaneous volume recently found in Cútar (Málaga). Their contents speak about the hard moments lived during the last times of Muslim political power in the Iberian Peninsula. Mention is made to the copyist and the possible author of the poems.

Key words: Arabic Literature; Strophic Poetry; Andalusian Arabic; Elegy; Sufism; AlAndalus; XV century.

A partir de la caída de Toledo en manos de Alfonso VI (1085) y escasos años después la de Valencia ante el Cid (1091), la pérdida progresiva de ciudades andalusíes - hasta la de la capital del reino nazarí- fue motivo de inspiración para los escritores árabes, que compusieron centenares de elegías, algunas de las cuales han llegado hasta nosotros, conservadas en compilaciones o divanes poéticos y también embutidas en maqāmas y risālas en prosa rimada ${ }^{1}$.

A esa temática de lamentos se contraponen los escritos de júbilo y de alegría por la recuperación -a veces efímera- para el islam de ciudades, castillos y alcazabas o por las victorias en batallas y peque-

${ }^{1}$ Recoge una treintena de estas composiciones al-Zayyāt, Rițā' al-mudun; a esta obra se refiere Fórneas Besteiro, "Romances fronterizos", p. 213. Una muestra de la producción en prosa en Sánchez, "Plany andalusí". 
ñas escaramuzas. Todo ello sin tener en cuenta las alabanzas que se hicieron a príncipes y generales norteafricanos, solicitando su ayuda o celebrando el envío de tropas a al-Andalus o su llegada a este lado del Estrecho.

Ambos temas de elegías y elogios han dado lugar a una producción tan amplia que no puedo detenerme ahora a exponerla detalladamente ni remitir a la inmensa bibliografía que existe ${ }^{2}$. Con todo, mencionaré como ejemplo los muchos versos que se escribieron a partir del siglo XIII, cuando por causa de la conquista cristiana se perdieron buen número de las más importantes ciudades andalusíes, pues sus representaciones poéticas constituyen modelos que con el tiempo resultaron inigualables e imposibles de superar. Cabe recordar la producción en prosa y en verso de los levantinos Ibn al-Abbār (m. 1260) y su compañero Ibn 'Amīra (m. 1259) ${ }^{3}$ o la casida nūniyya sobre la pérdida de las ciudades de al-Andalus compuesta por Abū-l-Baqā' al-Rund̄̄ (m. 1286) ${ }^{4}$. Para época más tardía puedo citar un ejemplo contrapuesto, es decir, un poema en el que se muestra alegría y vanagloria por la victoria: la casida que redactó el sultán nazarí Yūsuf III, en 1414, al recuperar de manos meriníes la fortaleza de Gibraltar; casi un canto de cisne andalusí de este género ${ }^{5}$.

Frente a las lamentaciones por la pérdida de al-Andalus o de sus ciudades por parte de los escritores árabes, la poesía castellana tiene también unos poemas que tratan el mismo tema a su manera: los llamados «romances fronterizos». Según Deyermond, «el suceso más temprano que se toca en éstos es el sitio de Baeza (1368), pero en general nos llevan al siglo $\mathrm{XV}{ }^{6}{ }^{6}$. Los de esa centuria (la de mayores éxitos cristianos en batalla), como los bien conocidos La pérdida de

2 Puede verse una aproximación al tema en el capítulo V, titulado «Cantos de guerra», del ya anticuado trabajo de Schack, Poesía y arte de los árabes. Para el siglo XI sigue siendo útil Pérès, La poésie andalouse, pp. 99-108. Otra visión del tema en Rubiera Mata, Literatura hispanoárabe, pp. 120-127 y 145-148.

${ }^{3}$ Hemos traducido varios textos literarios en prosa y verso de esta temática y autores en Labarta, Barceló y Veglison, València àrab en prosa $i$ vers.

${ }^{4}$ Al-Maqqarī, Azhār al-riyāẹ, vol. I, pp. 47-50. V. Ebied y Young, "Abū-1-Baqā̄' al-Rundī”.

5 Medio siglo después la fortaleza pasó a manos cristianas. Sobre el poema, Guennun (ed.), Dīwān mālik Garnātạ, pp. 109-110. Cfr. Moral Molina, "El dīwān de Yūsuf III".

${ }^{6}$ Deyermond, "Edad Media", p. 255. 
Alhama o Abenámar, se han venido considerando de inspiración árabe o, peor aún, escritos por un «moro castellanohablante», siguiendo en esto la senda de la maurofilia literaria del siglo XIX y primera mitad del $\mathrm{XX}^{7}$.

Fórneas, al ocuparse de la poesía de los últimos tiempos nazaríes, se preguntaba: «¿existió una poesía dialectal árabe "fronteriza” paralela a la de los romances? Formulada así la pregunta, suscitaría de inmediato su ramificación interrogativa en otras varias: ¿dónde están las muestras de esa poesía? ¿Quiénes fueron sus autores?» ${ }^{8}$. En su trabajo no nos da ninguna respuesta; pero puede afirmarse que esos ejemplos poéticos en dialectal existieron, aunque sean muy escasos los que se han conservado.

La mayor parte de las composiciones que tratan de las luchas entre musulmanes y cristianos en lugares fronterizos se escribieron en árabe clásico. Hay que advertir que el género elegíaco por la pérdida de ciudades, tratado en la poesía dialectal granadina a la que alude Fórneas, apenas tiene existencia, si no es la archiconocida y varias veces editada «elegía de Boabdil», que sólo nos ha llegado transcrita en caracteres latinos ${ }^{9}$.

Ante un panorama tan escaso, me ha parecido de interés dar a conocer en este trabajo dos poemillas sobre el tema del lamento por la ruina de al-Andalus, escritos en árabe dialectal y en forma estrófica, que vienen a sumarse a lo poco conservado.

\section{El manuscrito de Cútar}

Los dos poemas que aquí estudio forman parte de un códice misceláneo que, junto con otros dos manuscritos ocultos en una alacena, fue hallado de forma fortuita en el año 2003 al hacer obras en una vivienda de la villa malagueña de Cútar. Sobre las circunstancias y peripecias del hallazgo, su ingreso en el Archivo Histórico Provincial de Málaga, su proceso de restauración, encuadernación, característi-

7 Deyermond, "Edad Media", p. 213.

${ }^{8}$ Fórneas Besteiro, "Romances fronterizos", p. 199.

9 Gonzalo Argote de Molina, Discurso sobre la poesía castellana, Sevilla, 1575, f. 95; Nykl, Gonzalo Argote, pp. 17-19; Vázquez Ruiz, "La elegía de Boabdil"; Vázquez Ruiz, "De nuevo sobre la elegía de Boabdil"; Corriente, "A vueltas con las frases árabes”, esp. pp. 109-110. 
cas del papel y noticia de sus contenidos dan cuenta varios autores que se han ocupado de ellos ${ }^{10}$.

El códice en el que se contienen los textos que nos ocupan consta de 134 folios de papel $(222 \times 160 \mathrm{~mm})$ y lleva la signatura L-14030 de la sección de documentos islámicos ${ }^{11}$. En su descripción, Calero Secall (que lo denomina Libro II) afirma lo siguiente: «Poema estrófico de sólo un folio (f. 10r y 10v). Parece una $d u$ 'ā o súplica, que se presenta sin fecha, sin título, ni autor, aunque el autor anónimo especifique que «jamás ha sucedido en este mundo lo [que] ocurrió en al-Andalus, ni lo he visto en los libros de Historia.... ${ }^{12}$.

En realidad se trata de dos poemillas independientes, escritos en dos hojas que forman parte de un quinterno. Ocupan los folios $9 \mathrm{v}$ y 10r de un cuadernillo cuya primera y última hojas están en blanco (ff. 1r y 10v), a modo de cubiertas.

\section{El copista}

Si bien no consta el nombre del copista de estos poemas, la comparación de su letra con la que figura en otros muchos folios del mismo manuscrito, algunos de los cuales registran colofones que indican la fecha y el nombre del escribano, permite proponer a $\mathrm{Mu}-$ hammad b. 'Alī b. Muḥammad al-Ŷayyār al-Ansāân como autor material de la escritura. Por ese motivo, es posible datar la copia, de forma aproximada, entre las fechas que conocemos de su vida, tal vez hacia el año 1488, cuando -según confesión propia- el personaje se encontraba preso en Sevilla; tal vez después de 1490, año en el que fue nombrado imam de la mezquita del pueblo malagueño de Cútar ${ }^{13}$. Estas fechas extremas (1485-1495) vienen confirmadas tam-

${ }^{10}$ Calero Secall, "Los manuscritos árabes de Málaga"; Roser Nebot, "Libro I", "Cuadernillos del Libro II" y "Alcorán"; Espejo y Beny, "Book I from the collection of Arabic Manuscripts"; Espejo y Arias, "El Corán de Cútar"; Cruces Blanco, "La pervivencia y el valor de lo escrito", esp. pp. 283-298; González García y Plaza Villanos, “A propósito de papel con filigranas", esp. pp. 228-236.

${ }^{11} \mathrm{Mi}$ sincera gratitud a la doctora Esther Cruces Blanco, directora del Archivo Histórico Provincial de Málaga, que ha puesto a mi disposición una copia digitalizada del ms. de Cútar, ha comprobado personalmente detalles codicológicos de relevancia y ha autorizado la reproducción de los folios.

${ }^{12}$ Calero Secall, "Los manuscritos árabes de Málaga", p. 163.

${ }^{13}$ Cfr. Calero Secall, "Muḥammad al-Ŷayyāa". 
bién por el análisis de las filigranas del papel (ancla, trompa musical y mano), que permiten situar su difusión entre los años 1473 para la más temprana y 1500 como cronología última ${ }^{14}$.

La comparación caligráfica puede realizarse en los siguientes folios:

- 9r ${ }^{15}$ : colofón de un poema estrófico donde se asegura que «lo escribió el siervo que pide la misericordia de su Señor, el que espera su recompensa y el perdón de sus pecados», Muḥammad b. 'Alī al-Anșāiñ. En cuanto a la fecha, dice que «se completó en la mañana del día domingo del mes de rabī ${ }^{`}$ primero del año maltratado y humillado», expresión críptica que debe aludir a un hecho penoso, personal o colectivo; entre los acontecimientos posibles de la Granada nazarí de ese período, tal vez aluda al año de la conquista de Málaga (1487) o al de la pérdida de la capital del reino (1492).

- 24r: se cierra el poema de la Burda de al-Būsīīī con el siguiente colofón: «Se completó de mano del siervo, el necesitado (faqīr) de la misericordia de su Señor, el que espera Su recompensa y el perdón de sus pecados, Muḥammad b. 'Alī b. Muḥammad al-Ŷayyār alAnșārī». Señala que se terminó en Sevilla el domingo 27 de dū alqa'da del año 893/2 de noviembre de $1488{ }^{16}$.

- 92v: compilación de Cuarenta hadices cuyo colofón dice que «se completaron por la mano del que los escribió, el siervo, el mísero, el que espera la recompensa de su Señor y el perdón de sus pecados, Muhammad b. 'Alī al-Ŷayyār al-Anșārī. Lo escribió para sí mismo de su letra y puño perecedero, luego para quien Dios quiera». Eso ocurrió el lunes 7 de muharram del año 898/29 de octubre de $1492^{17}$.

- 12v: una anotación para recordar que Muhammad b. 'Alī alŶayyār entró de imam de la mezquita del pueblo de Cútar, de la taha de Comares, el primer día de ramadán del año 895/19 de julio de $1490^{18}$.

${ }^{14}$ Roser Nebot, "Cuadernillos del Libro II”, p. 253; González García y Plaza Villanos, "A propósito de papel con filigranas", pp. 228-236.

${ }^{15}$ Calero Secall, "Los manuscritos árabes de Málaga", p. 170, lám. 4.

${ }^{16}$ Calero Secall, "Los manuscritos árabes de Málaga", p. 164, § 6; Cruces Blanco, "La pervivencia y el valor de lo escrito", lám. VI.

${ }_{17}$ Calero Secall, "Los manuscritos árabes de Málaga", p. 164, § 9.

${ }^{18}$ Calero Secall, "Los manuscritos árabes de Málaga", p. 154. 


\section{Edición ${ }^{19}$}

\section{[Poema A]}

1 [f. 9v] allah dī al mașāb kif hal b nā $\diamond$

$\diamond$ wa_ŷamī‘ $-1 \_m u l u ̄ k$ salamū fī_nā

$\diamond$ man lā bakī qața yanūḥ 'alī_nā $\diamond$

$0 \diamond$ wāŷib huwa y_aja_y harqa ald_dumū' $\diamond$ wa_alladīi yatiq b_man_hu qadīr $\diamond$

$2 \diamond$ ḥadit_nā garīb miman yuwaraj $\diamond$ allahi dīi all_lahīb akbad_i tuṭbaj

$\diamond$ wa_rāyta alr_raqīb yaqșud wa_yanșah

0 atawba mani -llahi tantadar wa_llad̄ī yatiq bi_man_hu qadīr $\diamond$ wa lā ŷī nā yā hasrà jabar $\diamond /$

wa_f_ašyaj_nā wa_ațfal_nā al_sigar $\diamond /$

'alà mā ŷarà tabkī al_hiŷar $\diamond /$

'alà mā aṣab_nā min qihar $\diamond /$

wa_llahi 'an qarīb b_h yintașar $\diamond /$

wa_yuŷ'al fĩ asțār al_kutūb $\diamond /$

wa_raban an+qaẓā qādir yyatūb $\diamond /$

wa_yạ̣kum 'alay_nā b_-1_ḥurūb $\diamond$ /

yatī_nā b_hā muqīl al_i[t] $]$ ar $\diamond /$

wa_allah 'an [q]arīb bi_h yantașar $\diamond /$

$3 \diamond$ yā rabba al_ulà yā man_hu qādir $\diamond$ faraŷ mā nazal bi_nā 'an qarīb $\diamond /$

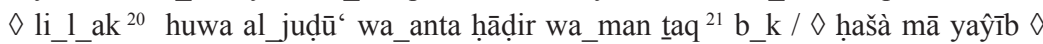
arḍa bi_-1_qạ̣ā wa_[bi]_-1_maqādir $\diamond /$ wa_man yangalab ma_1_u ŷawīb $\diamond$

0 aš yakūn ŷaw[ī]b ala_hu maglūb / wa_lladīi yatiq b_ma[n]_hu qadīr $\diamond /$ wa_huwa qad 'ayà mina_-1_șabar $\diamond$ wa_llah 'an qarīb bi_h yantașar $\diamond / /$

19 Transcribo con grafía latina, criterio aceptado hoy para textos poéticos dialectales. Sigo el sistema de las revistas Al-Andalus y Al-Qantara pero: raya baja ( _ ) separa pronombres enclíticos, preposiciones y conjunciones nexivas, el artículo y palabras indebidamente unidas de forma gráfica; el guión ( - ) indica alif sin vocal; el signo más $(+)$ une dos partes de una sola palabra, separada en el texto. Suplo entre corchetes ( [ ] ) consonantes y/o vocales que faltan por rotura del papel. Entre claudátors $(\{\})$ va lo que no pertenece al poema. El fragmento de texto de B escrito en el margen izquierdo va entre flechas ascendentes $(\uparrow)$. Opto por incluir la $>1<$ del artículo en voces que la asimilan, transcribiendo además doble la consonante asimilada cuando así lo hizo el copista. El símbolo $\diamond$ representa cuatro puntos, formando losange, en el ms. Señalo el cambio de línea con una barra ( / ) y el de página con barra doble ( // ). Alguna propuesta de corrección va en nota. Doy el número 0 al primer verso del prólogo y del estribillo; y un número correlativo al primero de cada estrofa. $>1$ ak $<$.

${ }^{20}$ Creo que el escribano trazó $>\mathrm{li}<\mathrm{y}$, sin tacharlo, continuó con $>\mathrm{lak}<$. Léase pues,

${ }^{21}$ Léase $>$ wataq $<$. 


\section{[Poema B]}

\section{[f. 10r] gayra_h}

0 ḥaṣal_nī al_hawà fì ḥukmi qāhir $\diamond$ li_hukma al_qạ̣à tarā_nī șābir $\diamond$

$1 \diamond$ ḥaddat yā ḥamām hada al_garāyb $\diamond$ kif rāyta ald_dumū' taŷrī sahāyib $\diamond$ wa_ablig -ls_salām ilà al_ḥabāyib $\diamond$

0 miskīn al_garīb -1lah 1_ū nāṣīr $\diamond$ li_ḥukma al_qaḍà tarā_nī șābir $\diamond$

$2 \diamond$ qaț̣a mā ŷarà fa_-ld_dunyā kul_ah $\diamond$ $\diamond$ wa_lā fì ktāb atwaraj aṣla_h $\diamond$ ḥakama al_qaḍa kif arāda -llah $\diamond$

0 bi_had̄ā hakamat al_ma[q]ādir $\diamond$ li_ḥukma al_qaḍà tarā_nī șābir $\diamond$

$3 \diamond$ kun șābir wa_lā taqnaṭ li_šidā $\diamond$ tal'ab $\{$ fî $\}$-ld_duhūr $\diamond$ bi_kul aḥaddā $\diamond$ awil wa_ajir li_kulli mudd̄ā

0 kuli man țalab la_-1_glb ajir li_ḥukma al_qaḍà tarā_nī / 个ṣābir $\diamond$ naqul ḥuŷat_ī ya'ṭi_nī ḥuŷaŷ $\diamond /$ muntaḍir li_sā'ata al_faraŷ $\diamond /$

fa_-1_garb li_man yakun ḥabīb $\diamond /$ min kitrat al_ašwaq wa_1l_lahīb / $\operatorname{man}\{\mathrm{i}\}$ ahli wațan_hum al_garīb $\diamond /$ kulli mā yŷ̄ ya'mal yuhāây $\diamond /$ muntaḍir li_sā'at al_faraḥ ${ }^{22}$ /

alladīi ŷarà fa_-1_andalus $\diamond /$ qahrat dī al_qulūb wa_dīi aln_nufūs $\diamond /$ usqī_nā yā ḥasrà d̄î̀ -1_kuyūs $\diamond /$ wa_lahịnā šaqī mina al_ḥaraŷ $\diamond /$ muntadịir li_sā'at al_faraŷ $\diamond /$ wa_bal_ak yahīb_ak man za‘ūm $\diamond /$ wa_ald_dunyā 'alà aḥada -š_tadūm $\diamond /$ wa_1_galb fanat bi_h al_qudūm $\diamond /$ fa_-lț_tlū' yyiṣāl 1_ajir daraŷ muntazirir li_sā'at al_faraŷ $\diamond \uparrow / /$

${ }^{22}$ Falta un punto diacrítico en esta palabra del estribillo. Léase, pues, >al_faraŷ $<$. 


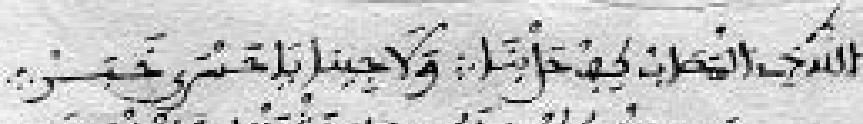

(1)

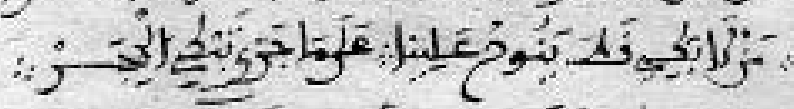

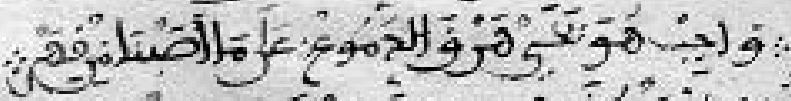

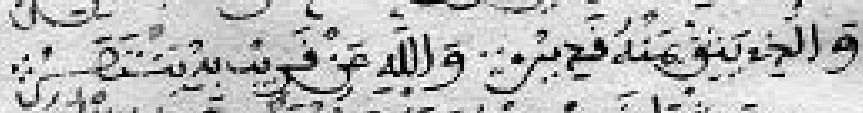

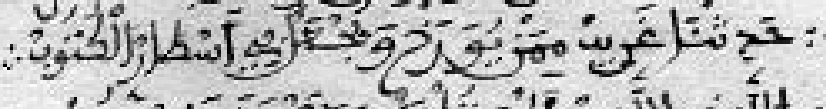

;

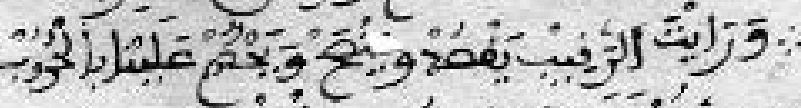

$\therefore$ ivf

$\therefore$ बैuب

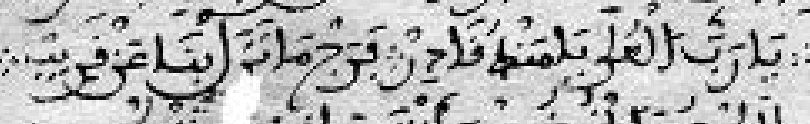

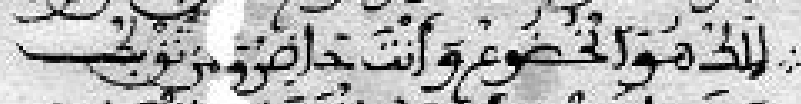

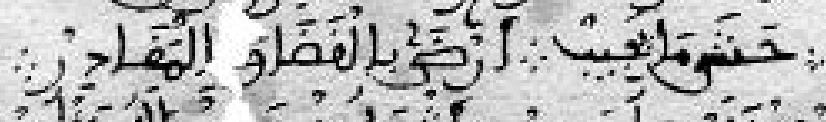

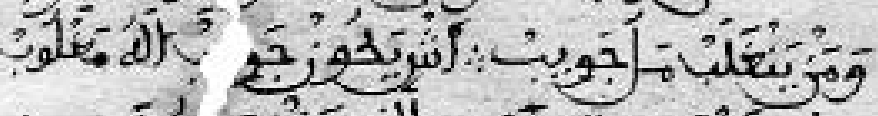

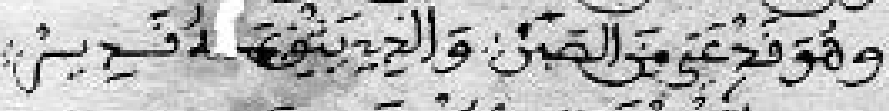

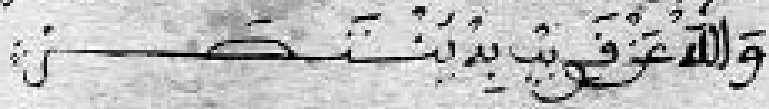

Lám. 1. Zéjel A. Archivo Histórico Provincial (Málaga), Documentos islámicos L-14030, f. 10v. 


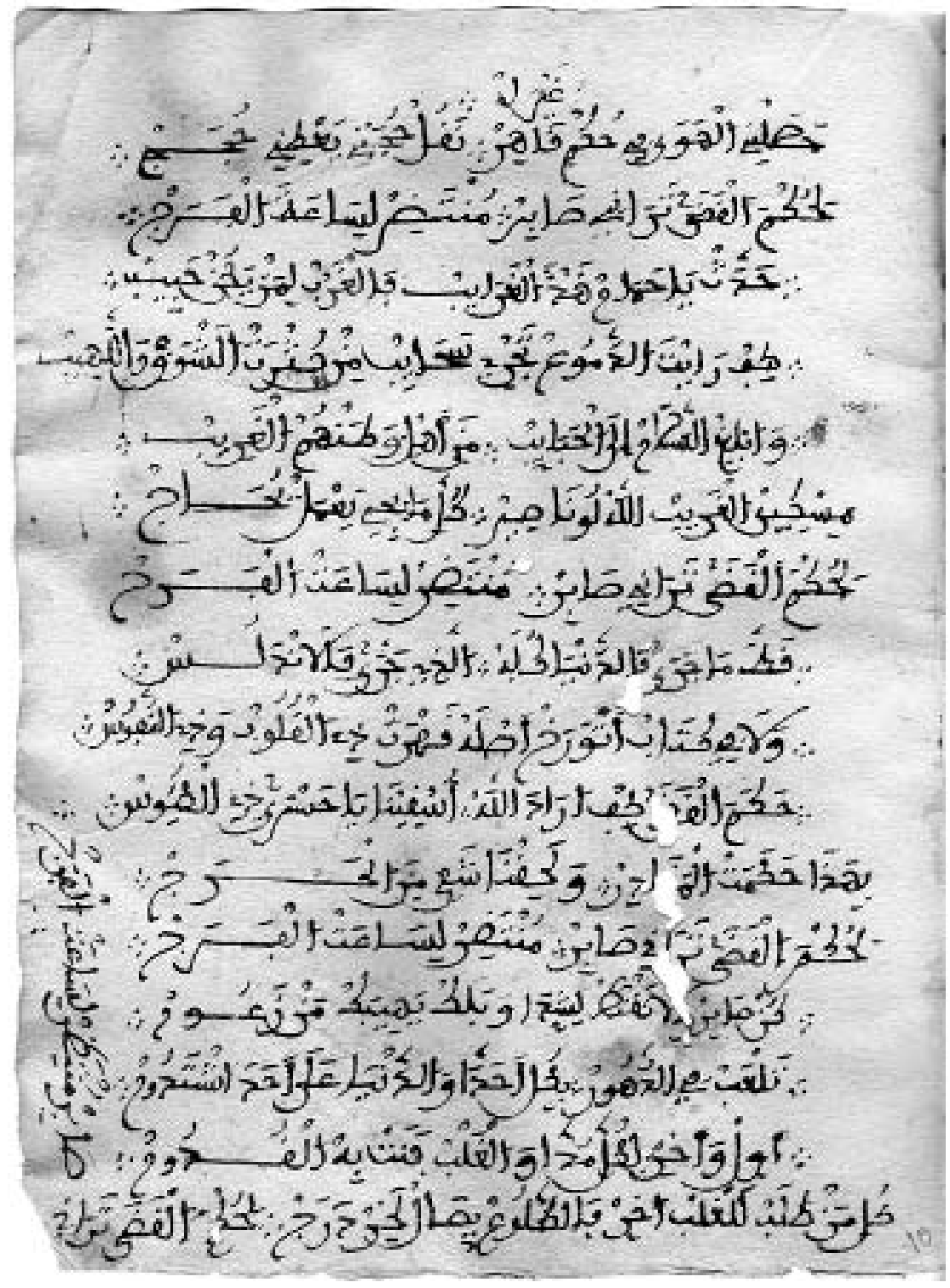

Lám. 2. Zéjel B. Archivo Histórico Provincial (Málaga), Documentos islámicos L-14030, f. 10r. 


\section{La lengua de los poemas}

El texto de los poemitas está totalmente vocalizado. El primer rasgo que llama la atención es que el ductus de ambos carece de $i$ ' $r a \bar{b} b$ y se ha utilizado un nivel de lengua con rasgos marcadamente dialectales. Así, la imāla de segundo grado, propia de fechas tardías del andalusí, es evidente en el poema $\mathrm{A}^{23}$, pero no en $\mathrm{B}$.

Como es bien sabido, en andalusí y otros dialectos occidentales, se producía confusión entre fonemas consonánticos velarizados y sus correspondientes no velarizados, lo cual da lugar a grafías que contravienen la norma clásica ${ }^{24}$. El escribano no ha marcado siempre la geminación, lo que contribuye a corroborar la sospecha de que este rasgo tenía carácter precario en andalusí ${ }^{25}$; pero da muestras de ser buen conocedor de la lengua clásica y capaz de restituir la šadda aunque no la realizara de forma oral. En algunos casos ha usado vocales largas no etimológicas para marcar de forma gráfíca el acento tónico ${ }^{26}$.

En B se documenta $>$ awil $<$ (Alc. ávil), en paralelo analógico con $>$ ajir $<$, normal en estándar andalusí ${ }^{27}$. El demostrativo dialectal $>\underline{d} \bar{i}<$

${ }^{23}$ En $>\hat{\mathrm{y}} \overline{1}<($ Alc. gi),$>$ bakī $<\mathrm{y}>$ ŷawīb $<$ (Alc. jeguíb), v. Corriente, El léxico árabe andalusí. No se halla en otras voces en las que se dan las mismas o parecidas condiciones, como $>$ wāŷib $<$ (Alc. guigib). La forma $>\hat{y} \hat{1}$ nnā $<$ está escrita igual en un zéjel de Ibn Zamrak; >yaŷîb $<$ en uno de Ibn al-Jațîb, cfr. Corriente, "Catorce cejeles", >jÍ na $<$ $3 / 3 / 4$ y >yijíbu< 15/3/4. Sobre la imāla, Corriente, "Árabe andalusí", pp. 356-35̄7 y Corriente, Árabe andalusí y lenguas romances, pp. 37-39; Labarta, "Algunos aspectos", pp. 288-290; Barceló, Minorías islámicas, pp. 167-168.

${ }^{24}$ Así, $>_{\mathrm{S}}<$ por $>\mathbf{s}<($ en $>$ sigar $<)$ y la confusión $>\mathrm{d}</>\mathbf{Z}<$, presente en todos los dialectos y reflejada en $>$ tantadar $<$ y $>$ an + qaza $<$; la doble grafía en $\mathrm{B}>$ muntadir $<\sim$ $>$ muntazir < será un descuido. Corriente, Árabe andalusí y lenguas romances, pp. 46, 50, 51, 52; Labarta, "Algunos aspectos", pp. 291-292; Barceló, Minorías islámicas, pp. 173-174; Vicente, "Los fonemas interdentales". >yanșah < rimando con >yuwaraj< y >tutbaj< indica problemas en el punto de realización de ambos fonemas que, por otro lado, se confundían a veces con $/ \%$ Corriente, "Árabe andalusí", p. 359; Corriente, Árabe andalusí y lenguas romances, p. 58; Barceló, Minorías islámicas, p. 176.

${ }^{25}$ Falta en $>$ qatạ $<$ (Alc. cátta y cáta) y $>$ yuwaraj< (Alc. muárrik), Corriente, Árabe andalusi y lenguas romances, pp. 64-65; Labarta, "Algunos aspectos", pp. 295-297; Barceló, Minorias islámicas, pp. 178 y 203.

${ }^{26}$ Así, en A: > kutūb< (Alc. cutúb) y >yaŷīb < (pero Alc. yégib); y donde se esperarían marcando acento tónico, usa vocales breves en vez de largas etimológicas: $>$ hadit $<,>$ akbad $\mathrm{i}<$. En el poema B hay largas por breves: $>$ za' $\mathbf{u}$ m $<,>$ šidā $<,>$ ahaddā $<$, $>$ muddā $<$, pero $>$ ya'tii ni $\overline{1}<,>$ yakun $<,>$ bal ak $<$. Corriente, Árabe andalusí y lenguas romances, pp. 60-62; Barceló, Minorías islámicas, pp. 177-178.

${ }^{27}$ Labarta, "Algunos aspectos”, p. 289 (>-wil<, éhuil); Barceló, Minorías islámicas, p. 187.

Al-Qantara XXXIII 1, 2012, pp. 169-199 ISSN 0211-3589 doi:10.3989/alqantara.2011.002 
(Alc. $d i$ «esto») se registra en los dos poemas ${ }^{28}$. Además de la forma clásica masculina allad $\bar{\imath}$ presente en el estribillo del poemita A, $>$ ala $\mathrm{hu}<$ puede identificarse con el relativo dialectal ${ }^{29}$.

Cabe destacar la vocalización no clásica de muchas formas verbales de imperfectivo ${ }^{30}$. Ambos poemas usan el interrogativo dialectal $>$ aš $<$, común en dialectos occidentales ${ }^{31}$. El único exclamativo es $>$ kif $<$, con monoptongación dialectal ${ }^{32}$.

Las preposiciones monoconsonánticas carecen de vocal final ante el artículo ${ }^{33}$ y $l i$ - se usa aglutinada en $>$ ma_1_ $u<$, donde la vocal final es el pronombre de tercera persona masculina singular ${ }^{34}$. Vemos la forma dialectal $>$ 'alī_nā $<$ (Alc. aâlé) junto a la estándar $>$ 'alay_nā $<$ $\mathrm{y}$ en $\mathrm{B}$ ilà aparece confundida con $l i{ }^{35}$.

\section{Estructura externa de los poemas}

El poema A es acéfalo y consta de tres estrofas, compuestas por tres versos de rima doble; en la primera estrofa ésta es $n \bar{a}-a r$, en la segunda $a j-\bar{u} b$ y en la tercera $i r-\bar{\imath} b$. Dos versos de doble rima común rematan cada estrofa. En estos estribillos el primer verso tiene rima libre y el otro estico $a r$; en el segundo verso la rima es $\bar{t} r$-ar.

El poema $\mathrm{B}$ se compone de un prólogo de dos versos de rima doble y tres estrofas, formadas por tres versos de rima doble y dos

${ }^{28}$ En A dos veces; en B como adjetivo con plurales: $>$ dī al_qulūb $<,>$ dī an nufūs $<$, $>$ dīi $-1 \_$kuyūs $<$y en alternancia con el deíctico clásico: $>$hada al garāyib $<$y $>$bi hade $\bar{a}<$. Labarta, “Algunos aspectos", p. 304; Barceló, Minorías islámicas, p. 189.

${ }^{29}$ Alc. «quien quiera que» aledí o allé, Torres Palomo, Bartolomé Dorador, pp. 4647; Barceló, Minorías islámicas, p. 190.

${ }^{30}$ En A, las masculinas $>$ yintașar $</>$ yantașar $<$, >yuwaraj $<$, >yangalab $<$ o las feme-

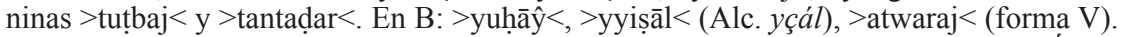
$V$. tabla de flexiones en Torres Palomo, Bartolomé Dorador, pp. 38-40; Corriente, Árabe andalusí y lenguas romances, p. 98; Barceló, Minorías islámicas, pp. 190-191.

${ }^{31}$ Sobre su uso andalusí, Torres Palomo, Bartolomé Dorador, pp. 46 y 48; Corriente, Árabe andalusí y lenguas romances, pp. 96-97.

32 Corriente, Árabe andalusí y lenguas romances, p. 41.

${ }^{33}$ Corriente, "Árabe andalusí”, p. 360. En A es $>$ f $<$; en B $>$ fa_ld_dunyā $<$, $>$ fa_-1_andalus $<$. Corriente, Árabe andalusí y lenguas romances, p. 70.

${ }^{34}$ Parece ser una forma lexicalizada, como lo es la fórmula vocativa $>$ y_aja_y< ‘hermano mío!', con tratamiento abreviado del vocativo y licencia poética clásica. Sobre el pronombre, Corriente, Árabe andalusí y lenguas romances, p. 93; Labarta, "Algunos aspectos", p. 303.

35 Como >1_ajir <. Corriente, "Árabe andalusís", p. 360; Corriente, Árabe andalusí y lenguas romances, p. 107. 
versos de rima doble común a los del prólogo. Éste y los dos versos de los estribillos riman: $i r-a \hat{y}$; los de la primera estrofa hacen $\bar{a} y i b-\bar{\imath} b$; la segunda, ah-us y la tercera $d \bar{a}-\bar{u} m$.

Esta alternancia de rimas podría hacer pensar que nos hallamos ante dos composiciones de tipo muwašša ${ }^{36}$, en concreto de la categoría que García Gómez denomina «moaxaja doble de esticos iguales» ${ }^{37}$. En ellos se utilizaba el árabe clásico, aunque aligerado de $i^{\prime} r a \bar{b} b$. Pero el hecho de que la lengua empleada en los de Cútar no pueda considerarse árabe clásico, por la presencia de muchos rasgos de árabe dialectal andalusí, me hace pensar que pertenecen al tipo denominado zaŷal ${ }^{38}$ o, si se prefiere, a lo que el mismo García Gómez llamó «zéjel amoaxajado» ${ }^{39}$ siguiendo la propuesta hecha por Stern en 1951 de «muwashshah-like zajal» ${ }^{40}$.

Un detalle de no menor importancia es que el segundo verso del prólogo se repite invariable al final de cada estrofa, como segundo verso del estribillo. Esto sugiere que, a la hora de interpretar musicalmente el poema, existía una interacción entre un cantor solista y un coro que se sumaba al canto repitiendo esa frase. No conozco ejemplos de zéjeles de temática profana que tengan esta estructura repetitiva, mientras que sí son abundantes los de tipo religioso que se documentan en la obra del místico granadino al-Šuštarī ${ }^{41}$. Ello hace pensar que nuestros poemitas tal vez procedían de un medio de carácter sufí, y que quizá fueron compuestos para ser recitados o cantados ${ }^{42}$ en el seno de una cofradía.

${ }^{36}$ Con carácter general, Monroe, "Zajal and Muwashshaha", vol. I, pp. 398-419. Este tipo de composición se describe en Scott Meisami y Starkey (ed.), Encyclopedia of Arabic Literature, vol. II, pp. 563-566.

${ }^{37}$ García Gómez, "Métrica de la moaxaja", en especial p. 45 y § 9, pp. 48-49.

${ }^{38}$ Scott Meisami y Starkey (ed.), EAL, vol. II, pp. 818-819.

39 García Gómez, "El Gran Zéjel marroquí", en especial 186, 1 (1989), p. 23.

40 Stern, "Studies on Ibn Quzmān", en Harvey (ed.), Hispano-Arabic Strophic Poetry, pp. 166-173.

${ }^{41}$ Corriente, Poesía estrófica, poemas nos $3,13-18,27,29,44-48,50,58,68,72$, 77, 81-86, 90, 96: II/1, 5, III/1, 2, 6, 21, 37; IV/1, 2, 5, 6, 8-10, 12, 13, 15, 16, 18, 19, $23 \mathrm{c}, 27,32-34,48,53$.

${ }^{2}$ Así lo consideró Massignon, "Recherches sur Shustari", pp. 251-276, donde en p. 263 alude al patrón rítmico y al modo musical y en pp. 268-270 señala los poemas que en los mss. llevan indicación de ritmo y modo. 


\section{Traducción}

\section{[Poema A]}

1 ¡Dios! ¿Cómo nos sobrevino esta desgracia Todos los reyes nos entregaron: a nosotros, Quien nunca lloró, plañe por nosotros;

0 ¡Hermano! Preciso es derramar llanto Quien confía en el Poderoso,

2 Nuestro suceso, extraño al historiador, ¡Dios! Esta llama abrasa mi corazón Has visto que el Vigilante propone y aconseja,

0 Se espera el arrepentimiento a Dios Quien confía en el Poderoso,

3 ¡Señor de las alturas! Tú que eres poderoso, Tuya es la sumisión. Tú estás presente.

0 Me contento con el decreto y el destino. ¿Qué respuesta tiene el que está vencido? Quien confía en el Poderoso, ¡malhaya! sin llegarnos noticia? nuestros viejos y nuestros niños pequeños. por lo que ocurrió, lloran las piedras. por la violencia que hemos sufrido. ¡por Dios! por Él pronto vencerá.

se pondrá en las líneas de los libros. ¡Cuántas veces se negó a arrepentirse quien podía! nos condena a las guerras. que nos trae el Perdonador de los pecados. ¡por Dios! por Él pronto vencerá.

alivia pronto lo que nos ha ocurrido.

Quien confía en Tí lleno está de lo que necesita. Quien es vencido no tiene respuesta. Le ha costado tener paciencia. ¡por Dios! por Él pronto vencerá.

[Poema B]

Otro

0 La pasión me alcanzó; sentencia obliga. A la sentencia del destino me ves resignado

1 ¡Paloma! ¡Cuenta estas rarezas Como viste el llanto correr a raudales ¡Lleva el saludo a los amados

0 ¡Pobre el extranjero! ¡Dios le auxilie! A la sentencia del destino me ves resignado

2 Nunca sucedió en todo el mundo Ni en libro se historió su fundamento: El destino sentenció como Dios quiso.

0 Esto sentenciaron Sus decretos. A la sentencia del destino me ves resignado

3 ¡Se paciente! ¡No desesperes ante el aprieto! Los tiempos juegan con cada uno Todo tiempo tiene principio y final.

0 Todo el que busca la victoria, al final, A la sentencia del destino me ves resignado
Digo: mi prueba me da argumentos. esperando la hora del alivio.

en Occidente a quien es querido, por los muchos deseos y el ardor! de sus compatriotas expatriados! Todo lo que se propone hacer es discutido. esperando la hora del alivio.

lo que pasó en al-Andalus, sumisión de estos corazones y estas almas. Se nos dieron a beber ¡malhaya! estos vasos. Nos alcanzó el infortunio de la dificultad. esperando la hora del alivio.

¡Tu mente te anima vanamente! pero el mundo ¿qué dura para uno? Por vencer perecen los valientes. al ascender llega al último grado. esperando la hora del alivio. 


\section{Época y temática}

En el poema A estamos ante una elegía, ante un lamento o rit $\underline{a} \bar{a}$; ya en la primera estrofa se expresa la queja por una desgracia que ha llegado a los creyentes por sorpresa. Lo confirma la expresión presente en su estribillo «iHermano! Preciso es derramar llanto», tan frecuente en casidas de carácter funerario. El leit-motiv que repite «quien confía en el Poderoso, por Él pronto vencerá» revela que el poeta es un musulmán que se halla en un ambiente de poder político islámico. Confía en que se alcanzará el éxito, tal vez la pronta recuperación de tierras, villas, fortalezas o ciudades perdidas ante el enemigo cristiano, aunque estas palabras no se mencionen. Es fácil sospechar que esa repentina desgracia haga alusión a la toma de un territorio o población. Como después sentencia que «todos los reyes nos entregaron», hay que convenir que estamos en un período concreto del proceso de desintegración del reino nazarí.

La petición a Dios -que en palabras del autor «nos condena a las guerras»- de que conceda el pronto alivio de «lo que nos ha ocurrido» es prueba suficiente de que en el pensamiento del poeta existe aún la posibilidad de revertir el resultado de la guerra. El tono es, sobre todo, manifiestamente religioso y, como suele ser habitual en este tipo de acontecimientos, es en los ambientes piadosos donde se culpa de los reveses políticos o de las amarguras de la vida a la falta de fe de los hombres y a las acciones reprobables de gobernantes y súbditos. Por lo tanto, el argumento que se esgrime es que si el arrepentimiento es sincero y los malos comportamientos se corrigen, la divinidad puede intervenir en beneficio de la comunidad y -si lo estima oportuno- ayudará a sus buenas gentes a recuperar lo perdido.

Desde la primera estrofa del zéjel B sabemos que el autor está, junto con otros «compatriotas expatriados», lejos de su casa y seres queridos que se hallan en «Occidente». Como en la estrofa 2 cita de manera expresa el territorio andalusí («nunca sucedió en todo el mundo lo que pasó en al-Andalus»), podemos aceptar que el poemilla hace referencia al reino nazarí y puede entenderse que el compositor estaba alejado de él en el momento de su inspiración, aunque no necesariamente fuera de la Península.

Su queja « Pobre el extranjero!» puede hacer referencia tanto a su expatriación como a su calidad de musulmán cautivo en tierra de 
cristianos ${ }^{43}$. Por eso inserta un léxico habitual en poemas que manifiestan los sentimientos de los exilados de la patria, comenzando por el estribillo, que repite «a la sentencia del destino me ves resignado, esperando la hora del alivio», es decir salir del cautiverio y volver a casa.

Para el autor es necesario someterse a la voluntad de Dios, ya que «el destino sentencia como Dios quiere» por eso «nos alcanzó el infortunio de la dificultad»; y además, es la divinidad la que permite exilios como el suyo: «esto sentenciaron Sus decretos». Es más, parece pertenecer a un entorno sufí, tan característico de los últimos tiempos granadinos, como desvelan sus referencias a lo efímero de la vida y el mundo terrenal, la ascensión al último grado donde se espera alcanzar la última victoria y otros aspectos religiosos que el poema recoge a pesar de su extrema brevedad ${ }^{44}$.

El poeta utiliza también otros temas de la poesía clásica, como la alusión de tipo báquico: reinterpreta la habitual escena del vino escanciado por el amante y la transforma en el mal trago que suponen las amargas vicisitudes de la vida: «Se nos dieron a beber ¡malhaya! estos vasos». Las alusiones a la poesía amorosa y los mensajes de los amantes se convierten, en la pluma del zejelero, en avisos que salen de parte del exilado hacia los seres queridos dejados en la patria. La paloma mensajera del poema amoroso lleva ahora a occidente, a los seres queridos, «el saludo de sus compatriotas expatriados» y les cuenta «estas rarezas».

Sin embargo, aunque algunas reflexiones sobre los infortunios de la vida (estrofa 3 de ambas composiciones) son habituales en las sentencias morales y aforismos que caracterizan el género hik$m a$ de la poesía clásica, creo que no se incluyeron por esa influencia literaria sino que podrían estar en relación con las Hikam o sentencias del mundo místico y sufí, como llamaron a los aforismos -hoy perdidos- del sevillano Abū Madyan (m. 594/1197-1198) y como llamó a su obra el egipcio Ibn 'Ațā' Allāh (m. 709/1309), vinculado con círculos sufíes granadinos a través del comentario versificado en metro raŷaz que de ella hizo Ibn 'Abbād de Ronda

\footnotetext{
${ }^{43}$ En una tradición recogida en la literatura aljamiada se menciona entre las «cosas algaribas», es decir desdichadas, «creyente que está en tierra de enemigos [al-'aduwes]», cfr. Hegyi, Cinco leyendas, f. 168r.

44 Es poco probable que el término garīb de este zéjel tenga los matices que destaca Fierro, "Spiritual Alienation", resumido en Fierro, "Revolución y tradición".
} 
(m. 1390), pues sus sentencias eran consideradas un auténtico manual de $\underline{d} i k r^{45}$.

Por lo tanto, en Cútar no se trataría de composiciones de tipo «popular», sino que estos zéjeles deberían atribuirse a un personaje con formación religiosa, cultura literaria árabe, que se manejaba bien con la lengua clásica, y de tendencias sufíes.

Respecto al período histórico que reflejan los poemas, quizá haya que pensar en los efectos que produjo en la población granadina el ataque de los reinos cristianos, sobre todo en el trienio 1485-1487, caracterizado por los hostigamientos de la tropa castellana en tierras malagueñas -atacando Ronda y su Serranía, Comares y Vélez- que acabarían con su entrada en Málaga capital tras largo y penoso asedio ${ }^{46}$.

Nada impediría, sin embargo, pensar que los poemas se refirieran a hechos de una etapa más antigua. No obstante, el contenido del zéjel $\mathrm{B}$ me inclina a creer más probable la cronología propuesta, ya que recoge una alusión directa a Málaga. Como se sabe, su territorio constituía el Occidente (al-garb) del reino de Granada, en oposición al Oriente con capital en Almería. Dicha referencia está en el primer verso de la primera estrofa: «Paloma! Cuenta estas rarezas en Occidente», es decir en tierras malagueñas.

\section{Contexto literario}

Ya he indicado que la copia de ambos zéjeles se puede establecer entre 1485 y 1495 . Se trata de un tiempo que coincide con la ofensiva y asalto cristianos contra el reino nazarí, iniciados en 1482 con la toma de Alhama y que concluyen con la caída de la capital del reino en enero de 1492. También se desprende del análisis de contenidos que ambos poemas podrían referirse a hechos acaecidos en el trienio 1485-1487.

El sentimiento de revancha que impregna los poemillas nos situa en el período granadino en el que ésta aún era posible. Ambos recuerdan versos que compusieron los poetas Abū-l-Husayn Ibn Furkūn

${ }^{45}$ Nwyia, Ibn 'Abbād de Ronda, pp. 92-100. Como es sabido Asín Palacios consideró a Ibn 'Abbād un precursor de san Juan de la Cruz.

${ }^{46}$ Trata estos hechos de guerra Ladero Quesada, Granada, p. 185 y ss. 
(m. h. 1417) ${ }^{47}$ y 'Abd al-Karīm al-Qaysī de Baza (m. 1489) ${ }^{48}$, más apreciados por los datos de carácter político que por su bondad literaria. En su lamento por la toma de Gibraltar, en 1462, el poeta de Baza al-Qaysī usa expresiones que son parecidas a las que utilizan nuestros poemillas:

La alegría y el bienestar nos son prohibidas mientras que en el corazón, por los sufrimientos, está la más grande de las heridas.

¡Ojalá quien decretó la toma la haga retornar! y haga desaparecer lo que se ha sufrido por la intensidad de la herida ${ }^{49}$.

Más desgarrados y desesperados son sus versos por la caída de su ciudad natal, hecho acontecido en 1489:

Por una gran desgracia fuimos sorprendidos y un grave suceso ocurrió en estas tierras

[...] No quedó allí, en este lugar, ningún ser humano al que no vieras que el exilio le sobreviniera ${ }^{50}$.

Los versos de Cútar carecen, sin embargo, del tono de derrota y desánimo de escritos posteriores a la caída de Granada. Así se aprecia en el poema de al-Daqqūn ${ }^{51}$ y resulta evidente en el conocido poema que se envió al sultán otomano desde Granada (al parecer en 1501 y con motivo de la primera revuelta de las Alpujarras) pidiendo su mediación para expatriarse de la Península:

haz que nos dejen emigrar de su tierra al Norte de África, la tierra de nuestros seres queridos, con nuestras pertenencias

pues preferimos emigrar a quedar en la descreencia, con poder, pero sin religión ${ }^{52}$.

${ }^{47}$ Ibn Furkūn, Dīwān; Palacios Romero, "Yūsuf III".

${ }^{48}$ Sobre este poeta: al-Qaysī al-Andalusī, Dīwān; Makkī, “"Abd al-Karīm bn Muhammad al-Qaysī al-Garnātị”"; Ben Šarīfa, al-Basțī; Charouiti Hasnaoui, "Conflictos en la frontera"; Castillo Castillo, "La pérdida de Archidona"; Castillo Castillo, "La conquista de Gibraltar"; Castillo Castillo, "Más elegías de al-Qaysī" y Castillo Castillo, “"Abd al-Karīm al-Qaysī".

${ }^{49}$ Castillo Castillo, "La conquista de Gibraltar", pp. 79-80.

${ }^{50}$ Castillo Castillo, "Más elegías de al-Qaysî", p. 115.

${ }^{51}$ El poema por la caída de Granada de Abū-l-'Abbas Ahmad b. Muhammad b. Yūsuf al-Ṣinhāŷ̄i, conocido por al-Daqqūn (m. 921/1515), en al-Maqqarī, Azhär al-riyād, vol. I, pp. 104-108. Cita la elegía Arié, "Panorama del florecimiento cultural", p. 44.

52 Al-Maqqarī, Azhār al-riyāed, vol. I, pp. 108-115, versos 98-99 (metro tawīl, rima - atī). Reproduce, estudia y traduce Monroe, "A curious Morisco". Versión en castellano en García-Arenal, Los moriscos, pp. 33-41. 
Y también corroboran ese desánimo y abatimiento otros textos escritos en época posterior al bautismo obligado de 1501, como las palabras que el Mancebo de Arévalo ${ }^{53}$ transcribe tomándolas de boca de Yūsuf Binnīgaš de Granada:

Yo he leído toda la talmuda ebráica y las leyes de los idólatras y otras pérdidas de duelos grandes -que todo fue de grande sentimiento y todos lloraron sus pérdidas- y tengo para mí que nadie lloró con tanta desventura como los hijos de Granada. No dudes mi dicho por ser yo uno de ellos y ser testigo de vista, que ví por mis ojos descarnecidas todas las nobles damas, ansí viudas como casadas, y ví vender en pública almoneda más de trecientas doncellas [...].

Hijo, yo no lloro lo pasado, pues a ello no hay retorno, pero lloro lo que tú verás si has vida y atiendes en esta tierra y en esta isla de España [...] Pues si ahora, en tan breve espacio, parece que ya nos sustentamos de acarreo, ¿qué harán cuando vengan las postreras otoñadas? [...] Si el rey de la conquista no guarda fidelidad, ¿qué aguardamos de sus sucesores? Todavía digo, hijo, que irá en aumento nuestra caída ${ }^{54}$.

\section{La autoría}

No consta, como ya he avanzado, el nombre del autor o autores de los dos zéjeles. De modo que podría zanjarse el asunto de la autoría considerándolos anónimos. Pero hay algunas noticias que podrían usarse para proponer una posible autoría.

Tratándose de zéjeles, escritos con alta probabilidad en tierras malagueñas o al menos en el reino de Granada, se podría caer en la tentación de atribuir los poemillas a un poeta de renombre, el conocido como "alfaquí 'Umar de Málaga», zejelero del que se ha conservado una maqāma fechada en rabī' II del año 844/30 de agosto de 1440. Sobre él llamó la atención Fernando de la Granja para quien este poeta «conocía muy a fondo los zéjeles de Ibn Quzmān y de Magdalīs según nos dice él mismo. El alfaquí 'Umar -escribe

${ }^{53}$ Sobre el Mancebo, Wiegers, Islamic Literature; López-Baralt, Huellas del Islam en la literatura española (versión en inglés Islam in Spanish Literature); Bernabé Pons, "Una fama sin biografía". Su Tratado ha sido editado por M.T. Narváez Córdova.

${ }^{54}$ Harvey, "Yūse Banegas", pp. 300-302. Reproduce una parte de este texto, con ortografía moderna, Ladero Quesada, Granada, p. 215. Según Ladero Quesada (Los mudéjares de Castilla, p. 153), los Venegas pertenecían a la familia del colaboracionista mudéjar Yahyà al-Nayyār. Seco de Lucena Paredes, "Notas para el estudio de Granada", esp. pp. 33-40 y apéndice y, sobre todo, Seco de Lucena Paredes, "Alamines y Venegas". Sobre el papel de los Granada-Venegas en época morisca, García-Arenal y Rodríguez Mediano, Un Oriente español, pp. 84-102. 
Maqqarī- es más visible que el fuego encima de la colina, y el vulgo sabe de memoria sus zéjeles, sus piezas en verso y sus maqāmas» ${ }^{55}$. Pienso que debe rechazarse esta atribución hipotética, no tanto por existir una distancia cronológica de al menos medio siglo entre la época en que vivió el autor de la maqāma y el período en que propongo datar los zéjeles de Cútar (que la haría imposible), cuanto por la falta de calidad literaria de los poemitas que nos ocupan, que desmerecerían la fama de que dicen gozaron las composiciones del alfaquí malagueño.

Otra opción que se puede tener en cuenta es que el autor-poeta fuera el propio escribano de una buena parte del manuscrito de Cútar. Trataré de justificarla. Muhammad b. 'Alī b. Muhammad al-Ŷayyār al-Anșārī, en el colofón que cierra el poema de la Burda, da noticia de que estaba cautivo en Sevilla. Me interesa retener dos datos: la bien conocida vinculación del poema de al-Būṣīīi con ambientes sufíes y milagreros; y por otro lado, el lugar exacto donde el personaje se hallaba y escribió la casida: > fì dar alž_zir.ntậ̣ū<

Nadie -que yo sepa- de cuantos se han ocupado del ms. de Cútar ha transcrito o interpretado esta grafía árabe, que esconde -creo- un término castellano: «la Casa del Adelantado» ${ }^{56}$. El autor usó un neologismo que reproduce el nombre de uno de los títulos de que gozó la nobleza de Castilla en tierras del sur peninsular. En efecto, el noble don Per Afán de Ribera (†1465), señor de varias plazas andaluzas, disfrutó en vida del título de Adelantado Mayor de Andalucía ${ }^{57}$. Casó a su hija Beatriz (†1470) con un hijo del Almirante de Castilla y tío del rey Católico, don Pedro Enríquez (†1492) quien, al enviudar, contrajo nupcias con su cuñada Catalina y a raíz de la muerte de su suegro gozó de dicho título ${ }^{58}$.

Hay noticias de la intervención de don Pedro en el asedio final a la ciudad de Granada, a donde acudió con un contingente de 6.000 peones

${ }_{55}$ Granja, Maqāmas y risālas andaluzas, pp. 205-206. Cfr. al-Maqqarī, Azhār al-riyā $\bar{d}$, vol. I, pp. 116-125 y 125-132, donde se encuentra la citada maqāma de la peste.

${ }_{56}$ Adaptaciones de voces romances y neologismos similares de época mudéjar y morisca en Barceló, Minorías islámicas, pp. 205-210; Barceló, "La llengua dels sarraïns", pp. 13-27 y Barceló, Arab i Català, pp. 50-64; se hallarán algunos más en Barceló y Labarta, Archivos moriscos, pp. 376-379.

${ }^{57}$ Franco Silva, "La villa de Espera".

${ }^{58}$ Cfr. Suárez Fernández, Los Reyes Católicos, p. 82 y ss. 
y 500 caballeros ${ }^{59}$. Antes de eso, consta que el Adelantado repobló y fortificó Setenil en 1482, año de la famosa toma de Alhama ${ }^{60}$. En 1483 participó en una algarada por la Axarquía malagueña, con malos resultados para los cristianos que sufrieron importantes pérdidas humanas ${ }^{61}$, y en la primavera de 1487 en el sitio y toma de Málaga.

En 1479 los Reyes Católicos concedieron al Adelantado disponer de la persona y bienes del mudéjar que fuera de Castilla al reino de Granada, por tierra o por mar, con cristianos o con ganados ${ }^{62}$. Aquellos esclavos musulmanes, más los que pudo adquirir por hechos de guerra, le permitieron contar con un considerable número de cautivos en su Casa y dominios ${ }^{63}$. Y consta que en la residencia sevillana de los Enríquez (que antes de pasar a la actual Casa de Pilatos ocupó el solar de la iglesia de San Luis de los franceses) ${ }^{64}$ tuvo muchos personajes granadinos cautivos y pendientes de canje ${ }^{65}$.

Ese sería el motivo de que Muhammad al-Ŷayyār estuviera en 1488, en condición de cautivo (asìr), en la Casa del Adelantado en Sevilla. Hay que suponerlo apresado por los cristianos entre la toma de Ronda (1485) y la de Málaga (1487). Como en las capitulaciones para la entrega de la ciudad, pactadas entre 'Alī al-Durdūš y don Gutierre de Cárdenas, muy detalladas en lo que toca al rescate de sus vecinos, se hizo constar de forma expresa que los cautivos no podrían volver a vivir en el reino granadino ${ }^{66}$ y sabemos que Muhammad al-Ŷayyār estaba en tierras malagueñas en 1490, parece poco probable que fuera apresado en 1487 al conquistarse Málaga.

No debería de extrañar que el posible autor de los poemillas se esmerara en escribir la Burda en la circunstancia de cautiverio en que se hallaba, porque se trata de un texto poético que, por su baraka,

${ }^{59}$ Carriazo, "Alegrías que hizo Sevilla".

${ }^{60}$ Arié, L'Espagne musulmane, p. 158.

${ }^{61}$ Mármol Carvajal (Historia del rebelión, 46a, libro I, cap. xiii), dice que «esta fué la batalla que dicen de las lomas de Cútar»; Guillén Robles, Málaga musulmana, pp. 142-154, aunque lo dató en 1482; Velázquez Basanta, "Relación histórica", p. 512.

${ }^{62}$ Ladero Quesada (Los mudéjares de Castilla, pp. 104-105), copia el documento expedido en Trujillo.

${ }^{63}$ Ladero Quesada, "La esclavitud por guerra"; Franco Silva, La esclavitud en Sevilla.

${ }^{64}$ González Moreno, Aportación a la historia de Sevilla, pp. 80-81.

${ }^{65} \mathrm{Su}$ viuda dejó 92 esclavos musulmanes en su testamento: Falcón Márquez, El Palacio de las Dueñas, p. 89.

${ }^{66}$ Entre otros, ha editado el documento Guillén Robles, Málaga musulmana, pp. 204-206, nota 1 .

Al-Qanțara XXXIII 1, 2012, pp. 169-199 ISSN 0211-3589 doi:10.3989/alqantara.2011.002 
había de ser consuelo y esperanza en aquel trance. Así debió de ser, porque, en su colofón, ruega a Dios que redima al esclavo (yafukku Allāh asìr) que ha escrito el poema y a cualquier otro cautivo musulmán ${ }^{67}$. Y esto, porque la casida de al-Būṣīīi siempre ha gozado del mérito de dispensar virtudes mágicas y curativas, que le atribuyen con frecuencia los círculos sufies ${ }^{68}$.

Muhammad al-Ŷayyār podría haberse ocupado en redactar el poema B estando en cautividad, antes de trasladarse a Cútar en 1490 para ocupar el puesto de imam en su mezquita. Si esto se acepta, el zéjel A podría haber sido redactado también por él, en época igual o posterior a su cautiverio, pues la amargura que trasluce estaría reflejando la que debió de producir la descomposición general del reino entre los intelectuales y religiosos granadinos, con los problemas de entendimiento de Abū-l-Ḥasan con su hermano Muhammad y su hijo Boabdil, sultanes con los que se derrumbó el estado nazarí en $1492{ }^{69}$.

\section{Alfaquíes, sufismo y profecías}

Fue tan corta la campaña de conquista, con la ulterior pérdida del territorio y del poder político, que no es posible precisar el momento en el que el desaliento (al que me he referido al analizar la temática de los poemas) dejó de ser sólo un estado de ánimo pasajero y se instaló entre los musulmanes con carácter permanente.

El análisis del contenido de los zéjeles da el perfil de un autor con estudios de literatura, lengua y religión. Su posible vinculación sufí no sorprende en el reino granadino, pues se detecta también en poetas de Corte, como el secretario de Boabdil al-'Uqaylī ${ }^{70}$. Si se acepta la hipótesis del copista-autor, estaríamos ante un alfaquí (él mismo se nombra al-faqi $[s i c])$, que se dice faqīr, término que en aquellos tiempos se daba a los miembros de una cofradía.

Poca relación tiene este individuo con los fuqahā' de Corte y con los que servían en mezquitas de barrios ricos de las ciudades y capitales nazaríes. En ese sentido, tal vez la familia de este Muhammad

${ }^{67}$ AHPM, ms. 14030, f. 24r. Al parecer, en el trance no le acompañó ningún miembro de la familia, pues no cita hijos, padres o hermanos.

${ }^{68}$ Cfr. Gabrieli, al-Burdatān, p. 23; Stetkevych, The Mantle Odes, esp. p. 83.

${ }^{69}$ Sobre esta opinión de la época, Granja, "Condena de Boabdil", esp. p. 149, nota 2.

${ }^{70}$ Cfr. sus referencias a la Burda en Moral, "La última misiva", esp. p. 250. 
no formara parte de una saga de encumbrados estudiosos, pues su onomástico al-Ŷayyār «el Calero» descubre antecedentes humildes; además fue un hombre que acabó regresando a tierras malagueñas para vivir modestamente como mudéjar en una diminuta alquería. Nuestro autor-escribano sería un ejemplo de los profesionales que en las etapas mudéjar y morisca tuvieron las funciones de maestro de escuela, recitador del Corán y redactor de cartas, actas y contratos ${ }^{71}$. A los del período de sumisión y bautismo forzado les cupo en suerte mantener viva la fe, junto con la esperanza del triunfo sobre la adversidad. Estaríamos ante las bases del pensamiento de las cofradías: entrega a Dios, arrepentimiento constante y alivio por la promesa divina de una vida mejor en el otro mundo. Pero no se quedaron solo en eso y se vieron obligados a acudir a otros recursos.

Cardaillac decía al presentar los textos proféticos que conocía que en las profecías moriscas «apparaissent les deux aspects propres à ce genre d'oeuvres: l'esperance d'une conquête politique, et la foi dans la victoire de l'Islam» ${ }^{72}$. Ambos aspectos enlazan con otro aceptado por la religión: la adivinación, accesible a cualquiera que conozca los métodos de sus ciencias (astrología, hadices apócrifos, etc.) y, en particular, a hombres místicos tocados de esa gracia por la divinidad, como Ibn al-'Arabī (m. 1240) o 'Abd al-Raḥmān al-Bisțamī (m. 1454).

En vida del místico rondeño Ibn 'Abbād (m. 1390) el sufismo malagueño tenía su máximo representante en Abū 'Abd Allāh alSāhilī (m. 754/1353), en cuya obra -titulada Bugyat al-sālik- menciona que alguien está reuniendo en Granada las cartas de dirección espiritual escritas por su padre ${ }^{73}$; recomendaciones que el texto árabe nombra wașay $\bar{a}$, cuyo singular wașiyya aparece en textos aljamiados convertido en alguaçías. Además del significado «testamento» propio del derecho islámico, esta palabra alguacía aparece en las bibliografías sobre moriscos asociada a los «pronósticos». Y a este tema quiero dedicar ahora unas líneas, a modo de cierre de este trabajo, porque me interesan aquellos escritos desde otra perspectiva.

${ }^{71}$ Sobre sus actividades: Albarracín Navarro, "Memorial a propósito de los alfaquíes", esp. p. 295. La bibliografía sobre esto no cabe en una nota a pie de página.

${ }^{72}$ Cardaillac, Morisques et chrétiens, pp. 49-56.

${ }^{73}$ Nwyia, Ibn 'Abbād de Ronda, p. 123. Sobre esta familia cfr. Rubiera, "Datos sobre una "madrasa»" y Mostafa, Edición y estudio de la Bugya. Existe otra edición de la obra de al-Sāhịī̄ a cargo de A.R. al-"Alamī. 
Me voy a referir a los tres «pronósticos» difundidos a través de la obra de Mármol Carvajal según la versión de Alonso del Castillo. Hay alguno versificado e incluso con nombre de autor ${ }^{74}$. Como ha dejado escrito el profesor Fahd, la ciencia del $\hat{y}$ afr (de donde procede el arabismo jofor) representa el destino y la fatalidad ( $\left.q a d \bar{a}^{\prime}\right)$ y la literatura a él vinculada, escrita en árabe clásico o dialectal, en verso o en prosa, se supone que contiene todo lo que ha sido y será en este mundo, de manera global o de forma parcial. Pero también, y en ambiente šící, el ŷafr sirvió para una interpretación espiritual y mística del Corán, en oposición a la exégesis sunní, y dio lugar a una literatura apocalíptica, de oráculos y ensoñaciones (malāhim) que ha gozado de gran difusión en el Magrib ${ }^{75}$. Y es en ese ambiente donde toma carta de naturaleza la figura de 'Alī, protagonista de tantas aventuras recogidas en la literatura de moriscos y también en uno de los pronósticos que nos ocupan ahora.

Llamo la atención sobre el hecho de que las fechas 96 o 93 que se citan en la versión de Alonso del Castillo no son en realidad 1596 ni 1593 como se viene aceptando. Las cifras de esos «pronósticos» son fechas islámicas en las versiones árabes y aljamiadas y se refieren a los períodos 902 a 926 y 909 de la Hégira, es decir 1496-1519 y 1503. Por consiguiente, el morisco que los leyera u oyera sólo podía confirmar en ellos lo que ya sabía que se había cumplido: conquista cristiana y bautismo ${ }^{76}$. Esto daba fuerza al pronóstico antiguo y credibilidad a los que se pudieran escribir entonces.

En cuanto a la pregunta que se estará haciendo el lector de qué relación tienen los «pronósticos» con los zéjeles de Cútar, cabe ahora preguntarse si no se trataba en realidad de lamentos por el presente, no por el futuro. Recuerdo ahora el sentimiento de desaliento a

${ }^{74}$ Los transmite Mármol Carvajal, Historia del rebelión, lib. III, cap. iii y ix. El poeta es Çayd el Guargali que versificó una profecía de Mahoma según Alonso del Castillo (Sumario, p. 84). Mármol señala en 1593 que El Guergalí «habrá como setenta años que murió», apud Cabanelas, El morisco granadino, p. 251. Guargali debe hacer referencia a la población argelina de Ouargla, que Juan León el Africano escribe Guargala.

${ }_{75}$ Fahd, "Djafr", en $E I^{2}$, vol. 2, 386a-388a. Sobre estos aspectos, García-Arenal, " UUn réconfort »" y García-Arenal, Messianism and Puritanical Reform.

${ }^{76}$ Sobre las fechas, Barceló y Labarta, Archivos moriscos, pp. 73-74, con referencias a otro pronóstico para 924-928/1518-1521, es decir las Germanías (1519-1521), y también doc. 146, 312-317. No he podido consultar la tesis doctoral de R. Iversen, Prophecy and Politics: Moriscos and Christians in Sixteenth and Seventeenth Century Spain, defendida en Princeton University en 2002. 
que antes me refería y que, por ejemplo, en el coetáneo poema-ŷafr de $\mathrm{Sa}^{\text {‘'̄ }} \mathrm{d}$ al-Wārqalī (m. h. 1520) aparece en estos términos al referirse -justamente- a la capital del Poniente granadino:

e Malaga se pondrá notoriamente, e no será ella sola, sino todas las cibdades; por que el avatimiento de las honras haze perder los reynos

e los que no rigieren por prudencia, acompañarles-ha toda tristeza e pesar ${ }^{77}$.

Y también nos recuerda las sentencias que recogen los zéjeles de Cútar cuando el autor del «pronóstico» dice:
quando el tiempo te espantare con los enemigos,
y te hiriere con la absencia e disension de tus amigos,
e te comprehendiere el temor por todas partes,
advierte en el artificio de vuestro Dios,
como acudirá con aquello que tú deseas de libertad muy propinca,
y empeçaran los luzeros y estrellas de ventura,
e te vendran mensagerias de descanso e albricias;
por tanto no desesperes que en lo secreto e oculto de la providencia de Dios
ay grandes maravillas e secretos [...].
di ¡ó mi Dios! dadme la misericordia de tu mano,
e aved compasion de mi, por que en esto ay maravilloso secreto ${ }^{78}$.

Pero todavía se puede añadir a aquellos «vaticinios» otra composición que estaba «en metros árabes y parecía ser lamentación»como explica Mármol- «en que se quejaban los moriscos de opresiones que los cristianos les hacían». Dice el lamento entre otras cosas:

E han puesto sobre nosotros á los judios que no tienen fe ni palabra, e cada dia buscan nuevas astuçias, mentiras, engaños e menosprecios é avatimientos é venganças [...] y este enemigo ha consentido en nosotros e á todos los judios nos ha presentado que hagan de nosotros lo que quisieren y que en ello no tengan culpa ${ }^{79}$.

Este lamento, lisa y llanamente, no corresponde a la época del escribano de Abenaboo (Aben Daud, a quien le fue requisado) y en la que se supone que se habría escrito (hacia 1568), porque en

${ }^{77}$ En ésta y otras citas sigo el Sumario, p. 83. El formato versificado que ofrezco aquí no está en Mármol ni en Alonso del Castillo.

${ }_{78}$ Castillo, Sumario, pp. 85-86.

${ }^{79}$ Castillo, Sumario, pp. 46 y 48; Mármol Carvajal, Historia del rebelión, libro III, final del capítulo IX. 
ese momento no quedaban judíos en la Península y menos que controlaran a los moriscos, cosa que sí ocurría en época de los Reyes Católicos. El lamento, por otro lado y al igual que los zéjeles de Cútar, abriga la esperanza de que vendrán tiempos mejores «y despues deste peligro de necesidad nos abran de dar el parabien, e Dios se apiadará de nosotros»; es decir todavía no estaba todo perdido $^{80}$.

Alonso del Castillo, a quien sigue Mármol, asegura que el lamento se encontraba dentro de un libro cuyo colofón decía: «E ansí acaba este libro por manos del siervo de Dios Mahomat Aben Deud, que de la misericordia de Dios tiene necesidad, el qual ruega e suplica á Dios quiera perdonar sus culpas e las de aquellos que este libro vieren e leyeren o oyeren leer ${ }^{81}$. Una redacción que coincide significativamente con los colofones que se leen en el ms. de Cútar.

Sospecho que estos poemas -zéjeles de Cútar, el jofor atribuido a El Guargali y la lamentación en verso conservada por los moriscosresponden a un mismo ambiente granadino: el de las cofradías sufies en la peor época política nazarí, cuando las milicias cristianas estaban conquistando el reino. No entendidos por las autoridades cristianas y manipulados a favor de éstas, esos viejos testimonios han pasado a la historiografía como algo que nunca fueron. Espero retomar el tema con estos y otros textos que me permitan confirmar y ampliar las hipótesis.

\section{Bibliografía}

Albarracín Navarro, J., "Memorial a propósito de los alfaquíes de Granada mudéjar", en Moral, C. del (ed.), En el epílogo del Islam andalusí. La Granada del siglo $X V$, Granada, Universidad, 2002, pp. 283-306.

Argote de Molina, G., Discurso sobre la poesía castellana, Sevilla, Hernando Díaz, 1575.

Arié, R., L'Espagne musulmane au temps des nașrides (1232-1492), Paris, Éditions de Boccard, 1973.

Arié, R., "Panorama del florecimiento cultural en la Granada nașrī del siglo XV", en Moral, C. del (ed.), En el epílogo del islam andalusi: la Granada del siglo XV, Granada, Universidad, 2002, pp. 23-45.

${ }^{80}$ Castillo, Sumario, p. 48; Mármol Carvajal, Historia del rebelión, libro III, final del capítulo IX.

${ }^{81}$ Castillo, Sumario, p. 42.

Al-Qanțara XXXIII 1, 2012, pp. 169-199 ISSN 0211-3589 doi:10.3989/alqantara.2011.002 
Barceló, C., Minorías islámicas en el País Valenciano, Valencia-Madrid, Universidad-Instituto Hispano-Árabe de Cultura, 1984.

Barceló, C., "La llengua dels sarraïns valencians", en Colomina, J. (ed.), Llengües en contacte als Regnes de València $i$ de Múrcia (segles XIII-XV), Alicante, Universitat, 1995, pp. 13-27.

Barceló, C., Àrab i Català. Contactes $i$ contrastos, Valencia, Publicacions de l'Abadia de Montserrat-Institut Interuniversitari de Filologia Valenciana, 2011.

Ben Šarīfa, M., al-Basțī, ājir šu 'arā' al-Andalus, Beyrut, Dār al-garb al-islāmī, 1985.

Bernabé Pons, L., "Una fama sin biografía: el Mancebo de Arévalo", en Echevarría Arsuaga, A. (ed.), Biografías mudéjares o la experiencia de ser minorías: biografías islámicas en la España cristiana, Madrid, CSIC, 2008, Estudios onomástico-biográficos de al-Andalus (EOBA) $\mathrm{XV}$, pp. 517-547.

Cabanelas, D., El morisco granadino Alonso del Castillo, Granada, Patronato de la Alhambra y Generalife, 1991.

Calero Secall, M. I., "Los manuscritos árabes de Málaga: los libros de un alfaquí de Cútar del siglo XV", en Viguera, M. J. y Castillo, C. (ed.), Los manuscritos árabes en España y Marruecos. Homenaje de Granada y Fez a Ibn Jaldún. Actas del Congreso Internacional (Granada, 2005), SevillaGranada, Consejería de Cultura de la Junta de Andalucía-Fundación El Legado Andalusí, 2006, pp. 151-174.

Calero Secall, M. I., "Muḥammad al-Ŷayyār, un alfaquí a través de los manuscritos de Cútar", en Echevarría Arsuaga, A. (ed.), Biografías mudéjares o la experiencia de ser minorías: biografías islámicas en la España cristiana, Madrid, CSIC, 2008, Estudios onomástico-biográficos de al-Andalus (EOBA) XV, pp. 385-416.

Cardaillac, L., Morisques et chrétiens. Un affrontement polémique (1492-1640), Paris, Klincksieck, 1977.

Carriazo, J. de M., “Alegrías que hizo Sevilla por la toma de Granada”, en En la frontera de Granada. Homenaje al profesor Carriazo, Granada, Universidad, 2002, pp. 537-550 [reimp. de la ed. de Sevilla, Universidad, 1971].

Castillo, A. del, Sumario é recopilacion de todo lo romançado por mi, el licenciado Alonso del Castillo, Gayangos, P. de (ed.), Memorial Histórico Español III, Madrid, Real Academia de la Historia, 1852.

Castillo Castillo, C., "La pérdida de Archidona poetizada por al-Basț̣̄", en Homenaje al prof. Jacinto Bosch Vilá, Granada, Universidad, 1991, vol. II, pp. 689-693.

Castillo Castillo, C., "La conquista de Gibraltar en el dīwān de 'Abd al-Karīm al-Qaysī”, Miscelánea de Estudios Árabes y Hebraicos (MEAH), 42-43 (1993-1994), pp. 73-80. 
Castillo Castillo, C., "Más elegías de al-Qaysī por pérdidas granadinas", en Homenaje al profesor José María Fórneas Besteiro, Granada, Universidad, 1995, vol. I, pp. 111-116.

Castillo Castillo, C., "A "Abd al-Karīm al-Qaysī y su dīwān”, en Castillo Casti1lo, C. (ed.), Estudios Nazaríes, Granada, Universidad, 1997, pp. 259-281.

Charouiti Hasnaoui, M., "Conflictos en la frontera granadino-castellana poetizados por al-Basti e Ibn Furkun (s. IX H-XV)", en Segura Artero, P. (coord.), Actas del Congreso La Frontera Oriental Nazarí como sujeto histórico (s. XIII-XVI) (Lorca-Vera, 22 a 24 de noviembre de 1994), Almería, Instituto de Estudios Almerienses, 1997, pp. 101-116.

El Corán de Cútar. I. Estudio Introductorio, Sevilla, Consejería de Cultura de la Junta de Andalucía, 2009.

Corriente, F., Poesía estrófica (cejeles y / o muwaššahāt) atribuida al místico granadino aš-Šuštarī (siglo XIII d.C.), Madrid, CSIC, 1988.

Corriente, F., El léxico árabe andalusí según P. de Alcalá, Madrid, Universidad Complutense, 1988.

Corriente, F., "Catorce cejeles de Ibn Zamrak y uno de Ibn Alxațîb", Anaquel de Estudios Árabes, 1 (1990), pp. 1-33.

Corriente, F., Árabe andalusí y lenguas romances, Madrid, MAPFRE, 1992.

Corriente, F., "A vueltas con las frases árabes y algunas hebreas incrustadas en las literaturas medievales hispánicas", Revista de Filología Española, 86, 1 (2006), pp. 105-126.

Corriente, F., “Árabe andalusí”, en Corriente, F. y Vicente, A. (ed.), Manual de dialectología neoárabe, Zaragoza, IEIOP, 2008, pp. 353-378.

Cruces Blanco, E., "La pervivencia y el valor de lo escrito: documentos árabes de la provincia de Málaga (ss. XIII-XVI)", en Martínez de Castilla, N. (ed.), Documentos y manuscritos árabes del occidente musulmán medieval, Madrid, CSIC, 2010, pp. 249-314.

Deyermond, A., 1. Edad Media, en Rico, F. (ed.), Historia y crítica de la literatura española, Barcelona, Editorial Crítica, 1980.

Deyermond, A., 1/1 Edad Media. Primer suplemento, en Rico, F. (ed.), Historia y crítica, Barcelona, Editorial Crítica, 1991.

Ebied, R. Y. y Young, M. J. L., “Abū-l-Baqā' al-Rundī and his elegy on Muslim Spain”, The Muslim World, 66, 1 (1976), pp. 29-34.

Espejo, T. y Beny, A., "Book I from the collection of Arabic Manuscripts from the Historical Archives of the Province of Málaga: An exemple of al-Andalus binding”, en Driscoll, M. J.y Mósesdóttir, R. (ed.), Care and Conservation of Manuscripts 11, Copenhagen, University of Copenhagen, 2009, pp. 121-133.

Fahd, T., "Djafr", en Bearman, P. J. et al., Encyclopédie de l'Islam, 2n edition, París, Brill, 1960-2005, 12 vols., vol. 2, pp. 386a-388a.

Falcón Márquez, T., El Palacio de las Dueñas y las casas-palacio sevillanas del siglo XVI, Sevilla, Fund. Aparejadores, 2003. 
Fierro, M., "Spiritual Alienation and Political Activism: the Gurabā' in alAndalus during the Sixth/Twelfth Century", Arabica, 47, 2 (2000), pp. 230260.

Fierro, M., "Revolución y tradición: algunos aspectos del mundo del saber en al-Andalus durante las épocas almorávide y almohade", en Ávila, M. L. y Fierro, M. (ed.) Biografías almohades II, Madrid, CSIC, 2000, Estudios onomástico-biográficos de al-Andalus (EOBA) X, pp. 131-165.

Fórneas Besteiro, J. M., "Romances fronterizos y poesía árabe. Nuevas reflexiones sobre viejas hipótesis: avance", en Castillo Castillo, C. (ed.), Estudios Nazaries, Granada, Universidad, 1997, pp. 193-223.

Franco Silva, A., La esclavitud en Sevilla y su tierra a fines de la Edad Media, Sevilla, Diputación Provincial, 1979.

Franco Silva, A., "La villa de Espera en la Baja Edad Media", en Martín Castellano, J., Velázquez Basanta, F. y Bustamante Costa, J. (coord.), Estudios de la Universidad de Cádiz ofrecidos a la memoria del profesor Braulio Justel Calabozo, Cádiz, Universidad, 1998, pp. 457-458.

Gabrieli, G., Al-Burdatān ovvero I due poemi arabi del mantello in lode di Maometto, Roma, Istituto per l'Oriente, 1972.

García Gómez, E., "Métrica de la moaxaja y métrica española. Aplicación de un nuevo método de medición completa al "Ğaiš" de Ben al-Hatị̄b", AlAndalus, 39 (1974), pp. 1-255.

García Gómez, E., "El Gran Zéjel marroquí del Ciego de Zarhūn (Versión personal)", Boletín de la Real Academia de la Historia, 186, 1 (1989), pp. 1-44 y 186, 2 (1989), pp. 137-208.

García-Arenal, M., Los moriscos, Madrid, Editora Nacional, 1975.

García-Arenal, M., “«Un réconfort pour ceux qui sont dans l’attente». Prophétie et millénarisme dans la péninsule Ibérique et au Maghreb $\left(\mathrm{XVI}^{\mathrm{e}}-\mathrm{XVII}{ }^{\mathrm{e}}\right.$ siècles)", Revue de l'Histoire des Religions, 220, 4 (2003), pp. 445-486.

García-Arenal, M., Messianism and Puritanical Reform: Mahdis of the Muslim West, Leiden, Brill, 2006.

García-Arenal, M. y Rodríguez Mediano, F., Un Oriente español. Los moriscos y el Sacromonte en tiempos de Contrarreforma, Madrid, Marcial Pons, 2010.

González García, S. y Plaza Villanos, B., “A propósito de papel con filigranas de época nazarí conservado en el Archivo Histórico provincial de Málaga", Baetica. Estudios de Arte, Geografia e Historia, 32 (2010), pp. 217-236.

González Moreno, J., Aportación a la historia de Sevilla, Sevilla, Castillejo, 1991. Granja, F. de la, "Condena de Boabdil por los alfaquíes de Granada", Al-Andalus, 36, 1 (1971), pp. 145-176.

Granja, F. de la, Maqāmas y risālas andaluzas. Traducciones y estudios, Madrid, Instituto Hispano-Arabe de Cultura, 1976.

Guennun, A. A. (ed.), Dīwān malik Garnāta Yūsuf al-țāliț, Tetuán, Instituto Muley al-Hasan, 1958. 
Guillén Robles, F., Málaga musulmana. Sucesos, antigüedades, ciencias y letras malagueñas durante la Edad Media, 2a ed., Málaga, Ayuntamiento, 1957.

Harvey, L. P., "Yūse Banegas. Un moro noble en Granada bajo los Reyes Católicos", Al-Andalus, 21, 2 (1956), pp. 297-302.

Harvey, L. P. (ed.), Hispano-Arabic Strophic Poetry, Oxford, Clarendon Press, 1974.

Hegyi, O., Cinco leyendas y otros relatos moriscos, Madrid, Gredos, 1981.

Ibn Furkūn, Abū al-Hasan b. Aḥmad, Dīwān, Ben Šarīfa, M. (ed.), Rabat, Académie Royale du Maroc, 1987.

Labarta, A., "Algunos aspectos del dialecto árabe valenciano en el siglo XVI a la luz del fondo de documentos del AHN", en Actas de las II Jornadas de Cultura Árabe e Islámica (1980), Madrid, Instituto Hispano-Arabe de Cultura, 1985, pp. 281-315.

Labarta, A., Barceló, C. y Veglison, J., València àrab en prosa $i$ vers. Edició, traducció, notes i índex, València, Universitat, 2011.

Ladero Quesada, M. A., "La esclavitud por guerra a fines del siglo XV: el caso de Málaga", Hispania, 105 (1967), pp. 63-88.

Ladero Quesada, M. A., Granada. Historia de un país islámico (1232-1571), 2a ed., Madrid, Gredos, 1979.

Ladero Quesada, M. A., Los mudéjares de Castilla y otros estudios de historia medieval andaluza, Granada, Universidad, 1989.

López-Baralt, L., Huellas del Islam en la literatura española: De Juan Ruiz a Juan Goytisolo, Madrid, Hiperión, 1985.

López-Baralt, L., Islam in Spanish Literature; from the Middle Ages to the present, Hurley, A. (trad.), Leiden-New York-Köln, Brill, 1992.

Makkī, M. 'A., "“Abd al-Karīm bn Muḥammad al-Qaysī al-Garnāṭ̂̄: ājir šu'arā’ al-Andalus", al-'Arabī (al-Kuwayt), 107 (1967), pp. 53-61.

Mancebo de Arévalo, Tratado [Tafsira], Narváez Córdova, M. T. (ed.), Madrid, Trotta, 2003.

Al-Maqqarī, Azhār al-riyāḍ fì ajbār 'Ayyāḍ, A'rāb, S.A., Tāwīt, M.b. et al. (ed.), Rabat, Șundūq ihyā̄' al-turāt al-islāmī, 1978-1980, 5 vols.

Mármol Carvajal, L. del, Historia del rebelión y castigo de los moriscos del reino de Granada, Málaga, Arguval, 1991 (facsímil de la ed. publicada en Historiadores de sucesos particulares, Madrid, Biblioteca de Autores Españoles, XXI, pp. 123-365, que toma como base la primera ed. de Málaga, 1600).

Massignon, L., "Recherches sur Shustari, poète andalou enterré a Damiette", en Mélanges offerts à William Marçais, Paris, G. P. Maisonneuve, 1950, pp. 251-276.

Monroe, J. T., "A curious Morisco Appeal to the Ottoman Empire", Al-Andalus, 31 (1966), pp. 281-303. 
Monroe, J. T., "Zajal and Muwashshaha. Hispano-Arabic poetry and the Romance tradition", en Jayyusi, S. K. (ed.), The legacy of Muslim Spain, Leiden-New York-Köln, Brill, 1994, vol. I, pp. 398-419.

Moral Molina, C. del, "El dīwān de Yūsuf III y el sitio de Gibraltar", en Homenaje al prof. Dario Cabanelas Rodríguez, O.F.M., con motivo de su LXX aniversario, Granada, Universidad, 1987, vol. II, pp. 79-96.

Moral Molina, C. del, "La última misiva diplomática de al-Andalus: la Risāla de al-'Uqaylī, enviada por Boabdil al sultán de Fez en demanda de asilo", en Moral, C. del (ed.), En el epílogo del Islam andalusí. La Granada del siglo XV, Granada, Universidad, 2002, pp. 201-259.

Mostafa, R., Edición y estudio de la Bugya de al-Sahili, sufi malagueño del siglo VIII H. XIV J.C., Tetuán, Manšūrāt al-Ŷāmi`a al-Magribiyya li-1Dirāsat al-Andalusiyya, 2004.

Nwyia, P., Un mystique prédicateur a la Qarawīȳn de Fès. Ibn 'Abbād de Ronda (1332-1390), Beirut, Institut de Lettres Orientales de Beyrouth, 1961.

Nykl, A.R. (ed.), Gonzalo Argote y de Molina's Discurso sobre la poesía castellana contenida en este libro (i.e., El Libro de Patronio o El Conde Lucanor) and Bartholomaeus Gjorgjevic, Baltimore, Furst, 1948.

Palacios Romero, A., "Yūsuf III en el diván de Ibn Furkūn", Al-Andalus-Magreb, Estudios Árabes e Islámicos, 7 (1999), pp. 255-269.

Pérès, H., La poésie andalouse en arabe classique au XI siècle, $2^{\mathrm{e}}$ ed., Paris, Adrien-Maisonneuve, 1953.

Pérès, H., Esplendor de al-Andalus. La poesía andaluza en árabe clásico en el siglo XI: sus aspectos generales, sus principales temas y su valor documental, García-Arenal, M. (trad.), Madrid, Hiperión,1983.

Al-Qaysī al-Andalusī, 'Abd al-Karīm, Dīwān, Šayja, Ŷ. y al-Ṭarābulsī, M. H. (ed.), Cartago, Bayt al-hikma, 1988.

Roser Nebot, N., [Fichas catalográficas de] "Libro I (Libro del alfaquí de Cútar, Muhammad Ibn al-Yayyar)", "Cuadernillos del Libro II (manuscritos de Cútar)" y "Alcorán (Manuscritos de Cútar)", en Viguera Molins, M. J. (coord.), Malaqa: entre Malaca y Málaga [catálogo de la exposición], Málaga, Universidad, 2009, pp. 251-255.

Rubiera Mata, M. J., "Datos sobre una «madrasa» en Málaga anterior a la nașrí de Granada”, Al-Andalus, 35, 1 (1970), pp. 223-226.

Rubiera Mata, M. J., Literatura hispanoárabe, Madrid, MAPFRE, 1992.

Al-Sāhilīi, Abū 'Abd Allāh, Bugyat al-sālik fì ašraf al-masālik, al-'Alamī, A. R. (ed.), Rabat, Wizārat al-awqāf wa-l-šu’ūn al-islāmiyya, 2003.

Sánchez, M., "Plany andalusí per la pèrdua de València", L’Avenç, 16 (1979), pp. 44-48.

Schack, A. F., Poesía y arte de los árabes de España y Sicilia, Valera, J. (trad.), 3. ${ }^{a}$ ed., Madrid, 1881, 3 vols. (reimp. Madrid, Hiperión, 1988). 
Scott Meisami, J. y Starkey, P. (ed.), Encyclopedia of Arabic Literature (EAL), London-New York, Routledge, 1998, 2 vols.

Seco de Lucena Paredes, L., "Notas para el estudio de Granada bajo la dominación musulmana", Miscelánea de Estudios Árabes y Hebraicos (MEAH), 1 (1952), pp. 27-49.

Seco de Lucena Paredes, L., "Alamines y Venegas cortesanos de los nașries", Miscelánea de Estudios Árabes y Hebraicos (MEAH), 10 (1961), pp. 127-42.

Stern, S. M., "Studies on Ibn Quzmān”, Al-Andalus, 16 (1951), pp. 379-425.

Stern, S. M., Hispano-Arabic Strophic Poetry (selected and edited by L. P. Harvey), Oxford, Clarendon Press, 1974.

Stetkevych, S. P., The Mantle Odes. Arabic Praise Poems to the Prophet Muhammad, Indiana, Indiana University Press, 2010.

Suárez Fernández, L., Los Reyes Católicos. Fundamentos de la monarquía, Madrid, Rialp, 1989.

Torres Palomo, M. P., Bartolomé Dorador y el árabe dialectal andaluz, Granada, Universidad, 1971.

Vázquez Ruiz, J., "La elegía de Boabdil (Contribución al estudio del árabe granadino)", Boletín de la Universidad de Granada, 22 (1950), pp. 277-291.

Vázquez Ruiz, J., "De nuevo sobre la elegía de Boabdil", Revista del Instituto Egipcio de Estudios Islámicos, 20 (1979-1980), pp. 65-68.

Velázquez Basanta, F. N., "Relación histórica sobre las prostrimerías del Reino de Granada, según Aḥmad al-Maqqarī (s. XVII)", en Moral, C. del (ed.), En el epílogo del Islam andalusí. La Granada del siglo XV, Granada, Universidad, 2002, pp. 481-554.

Vicente, A., "Los fonemas interdentales en los dialectos árabes magrebíes", Al-Andalus-Magreb, Estudios Árabes e Islámicos, 7 (1999), pp. 317-333.

Wiegers, G., Islamic Literature in Spanish \& Aljamiado Yça of Segovia (fl. 1450), His Antecedents \& Successors, Leiden-New York-Köln, Brill, 1994.

Al-Zayyāt, 'A. A. M., Rițāa' al-mudun fì al-ši 'r al-andalusī, Bengazi, Ŷāmi'at Qāryūnus, 1990.

Recibido: $10 / 08 / 2011$

Aceptado: 09/12/2011 